\title{
A Systematic Approach to Studying Fisheries Governance
}

\section{Xavier Basurto and Mateja Nenadovic}

Duke University

\begin{abstract}
How can policies for governing marine fisheries become more effective? How can we engage in developing a new science of fisheries governance that promotes knowledge accumulation and collective learning? We look into these issues by reviewing the current social-ecological status of marine fisheries, common policy approaches in place to govern them, and key learned lessons and shortcomings. While great efforts have been made towards understanding marine governance in the last 50 years, if we are to meet the current and upcoming challenges facing global fisheries, we need to engage with systematic knowledge accumulation about governance performance. To this end we report on a novel classificatory framework which, while nascent, could offer the potential to help us move in that direction.
\end{abstract}

Fisheries are an important source of food and income for about 8 per cent of the world's population ( $\sim 520$ million people) who depend directly or indirectly on the fishing sector (FAO, 2009). As a commodity, fish and fish-related products are the most highly traded food items globally (FAO, 2009). Adequate fisheries governance is necessary to guarantee the sustainability of fisheries-related activities and overall ocean health (Gelcich et al., 2010; Jackson et al., 2001; Worm et al., 2006). Everywhere in the planet oceans shape people's lives whether they eat fish or not, and whether or not they have ever set foot on a sandy beach or experienced the mesmerizing beauty of a coral reef. Covering some 71 per cent of the Earth and holding more than 97 per cent of surface water, oceans regulate climate, buffer carbon dioxide production, enable global commerce, provide us with a number of renewable and non-renewable resources and serve as a source of inspiration, recreation and discovery.

Despite the global importance of marine fisheries and important advances in policy analysis (Costello et al., 2008), we lack a policy fisheries science capable of providing clear guidelines towards understanding why some policies work better than others and under what conditions. The goal of this article is to call attention to a novel approach that could lead policy analysts in that direction. To develop our argument we review the most current global fisheries literature and briefly summarize the main policy approaches in use to govern global fisheries. Our review illustrates, on the one hand, the complexity and magnitude of the social-ecological challenges facing global fisheries today, and on the other, the availability of numerous policy tools and lessons learned regarding the performance of policies. Unfortunately, these lessons lack integration, making it challenging to develop a systematic understanding and appropriate metrics of policy performance. We argue that addressing the challenges facing global fisheries today demands a systematic approach to governance analysis and that, as in any other science, the basis lies in a classificatory system capable of organizing knowledge and enabling knowledge accumulation and its eventual integration for faster learning.

In the context of fisheries governance such a classificatory system should show at least two main design characteristics: to recognize fisheries as complex adaptive systems; and to treat social and ecological factors as equally important from the outset. As a conclusion we hypothesize that scholars working towards building a classificatory system - a very ambitious goal in itself and who are capable of addressing the collective action problems inherent in developing such a multidisciplinary classificatory system, will be in a better position to address fisheries governance challenges successfully than those groups that do not engage in such an enterprise.

To elaborate on the above, we provide a brief review of the status of global fisheries and the main policy approaches used to govern them. In the final section we present and briefly describe what such a classificatory system could look like, using a proof of concept study as an illustration, and end with some cautionary notes. 


\section{Major trends in global marine fisheries}

The world's appetite for seafood keeps increasing, and an estimated additional 35-40 million tonnes of seafood will be needed by 2030 to satisfy global demand (Delgado et al., 2003; Ye, 1999), even though marine fisheries production reached its peak during the 1980s and since then has been in gradual decline (Pauly et al., 2005). Most recent global estimates put the marine fisheries catch at 82 million tonnes in 2006 (FAO, 2009). Aquaculture contributed an additional 52 million tonnes and is expected to surpass capture fisheries in the near future as a source of fish for human consumption. While aquaculture could reduce the pressure on capture fisheries, if some of its current practices remain unchanged, aquaculture will contribute to increased pressure on fishing (Pauly et al., 2002).

All major recent global fisheries reports agree that most fishing stocks are already fully exploited or overexploited, indicating that fishing has reached its maximum exploitation levels or is being exploited above sustainable levels (FAO, 2005, 2009). Of the 441 assessed fish stocks harvested by industrial fisheries worldwide, the Food and Agriculture Organization of the United Nations (FAO) reports that some 70 per cent are fully exploited or overexploited (FAO, 2005) (Figure 1). Worm et al. (2006, 2009) report that catches of 65 per cent of all fished species have declined by more than 90 per cent below the historic maximum and some 63 per cent of all commercial species require rebuilding. While scholars have also documented examples of succesful fisheries which have either improved over time or did not cause overfishing in the first place (Hampton et al., 2005; Hilborn et al., 2005a; Murawski et al., 2007), the effects of overfishing are now felt in all major ocean ecosystems, from coastal seas (Lotze et al., 2006; Myers et al.,

Figure 1. Changes in the exploitation levels of major global marine fisheries from 1950 to 2006.

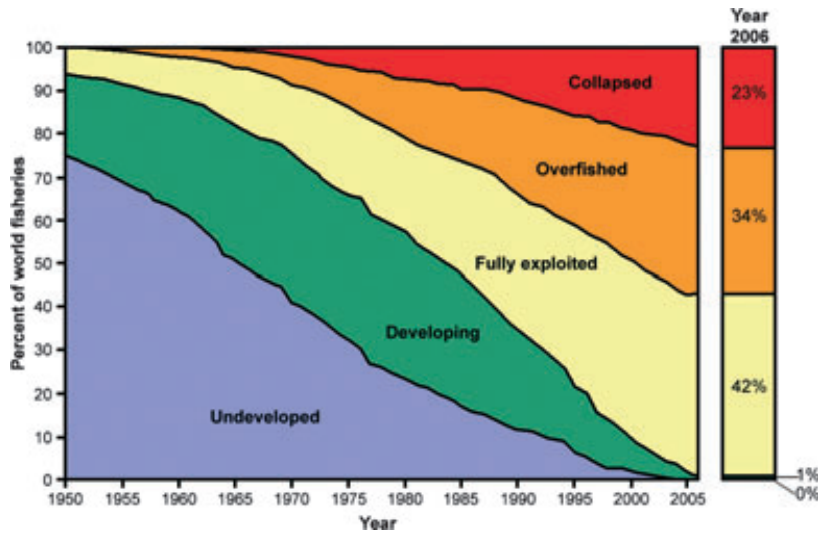

Source: Graph shown in FishBase (http://www.fishbase.org, accessed October 2010) based on methods in Froese and Kesner-Reyes (2002).
2007) to open seas (Myers and Worm, 2003) and deep oceans (Devine et al., 2006).

In terms of employment, there are roughly 43.5 million fishers and aquaculturists worldwide (FAO, 2009). If post-fishing activities, for example fish processing, boat building and maintenance, are taken into account, this number expands to 170 million (FAO, 2009). This corresponds to a gross global revenue of approximately US\$86 billion in 2006 (FAO, 2009). However, the indirect economic impact of fisheries is considerably larger. According to a study conducted by Dyck and Sumaila (2010), every US\$1 of fisheries sector production generates an additional US\$3 throughout the global economy.

The small-scale fishing (SSF) sector deserves a separate mention due to its increasingly recognized role in food security and livelihoods for a large number of people in developing countries (Bènè, 2006; Berkes et al., 2001). Unlike industrial fisheries, SSFs are multispecific - they target different species throughout the year - operate at fine scales, rotate fishing gear, use a large portion of the catch for subsistence purposes and land the catch in different sites throughout the year. SSFs' adaptability to local social, ecological and economic conditions gives rise to a very diverse sector that is complex to characterize (FAO, 2004; Johnson, 2006). As a result, it is a considerable challenge to generate reliable estimates of their catch (see Figures 2 and 3 for examples of SSFs and industrialized fisheries). For these reasons it is unclear how well represented SSFs are in global fisheries reports. Some estimates put SSFs' catch at approximately 30 million tonnes annually (Berkes et al., 2001; FAO and WorldFish Center, 2008; Pauly, 2006), but most of the catch is thought to go unaccounted for because it is used directly for subsistence purposes or traded at local markets and therefore not incorporated into official landings data. For example, Dalzell et al. (1996) found that for communities of the South Pacific close to 80 per cent of the total yearly catch ( $\sim 100$ thousand tonnes) during the early 1990s was used for subsistence purposes. Even though there are a number of SSFs that exhibit sucessful management of their resources (Basurto and Coleman, 2010; Cordell and McKean, 1992), some over long periods of time (Johannes, 2002), recent demographic and cultural changes as well as increased market integration of many isolated coastal communities have resulted in a rise in fishing pressure and subsequent overfishing of local fish stocks by SSFs (Cinner and McClanahan, 2006; Hawkins and Roberts, 2004; Newton et al., 2007).

Increasing global demand for seafood products puts pressure not only on fish stocks but also on entire marine ecosystems, their structure and their functionality. Apart from the direct impact on fish stocks, overfishing can alter and simplify the food web structure and reduce biodiversity, while certain fishing practices can destroy habitat (Frank et al., 2005; Norse and Watling, 1999; 
Figure 2. Examples of small-scale fishing operations: (a) hookah diving in the Gulf of California, Mexico; (b) stilt fishing in Sri Lanka; (c) crab fishing in Madagascar; and (d) fish trapping in Vietnam.
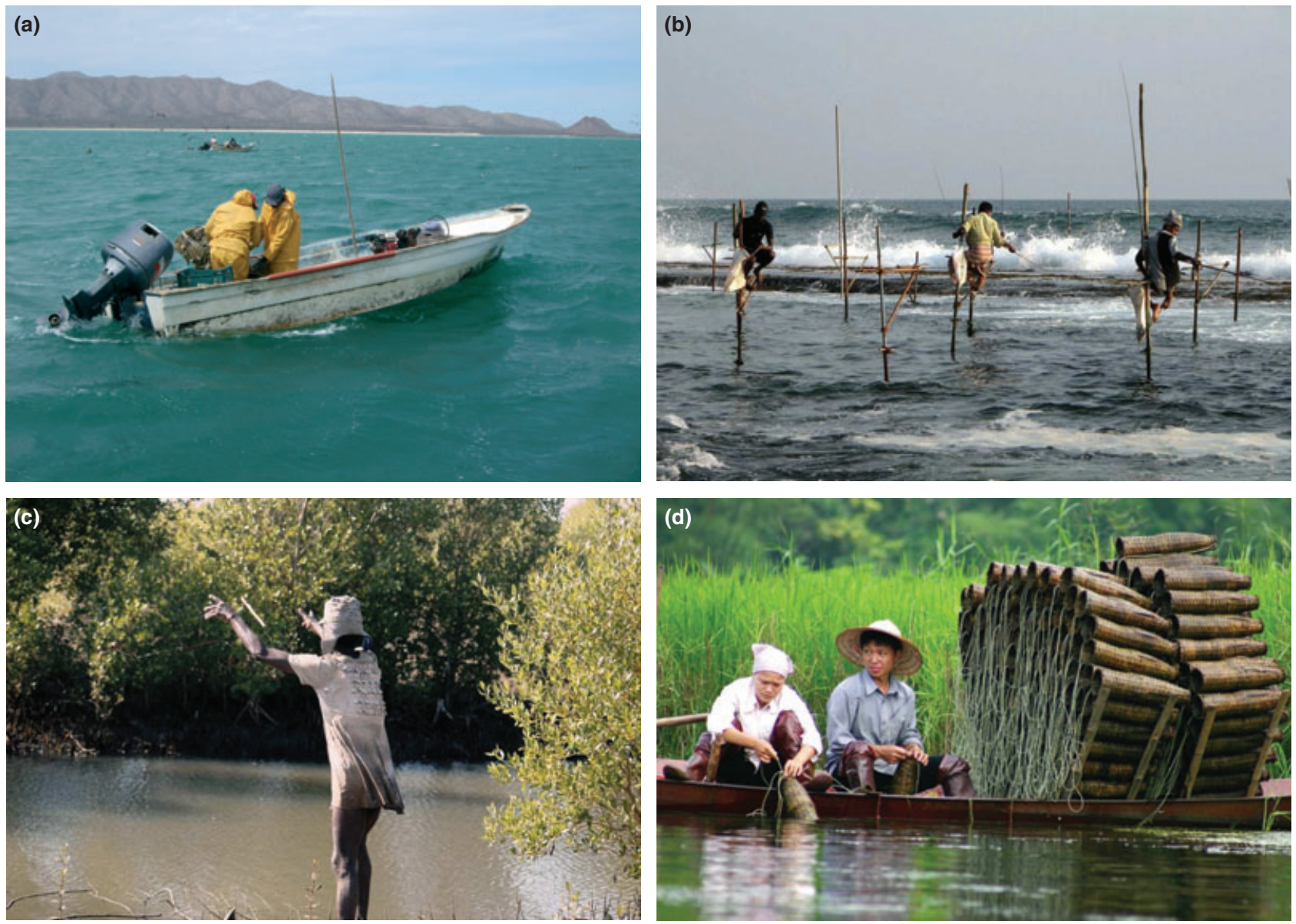

Source: Photo credits: (a) Xavier Basurto, 2008; (b) Bernard Gagnon, 2006/Wikimedia; (c) Benjamin De Ridder, 2008/Marine Photobank; (d) Petr Ruzicka, 2006/Wikimedia.

Worm et al., 2006). It has been estimated that losses due to overfishing and inadequate management, in terms of revenue, can total up to US\$36 billion a year (Srinivasan et al., 2010). This figure would likely increase to tens of trillions of dollars per year if we were to take into account the effects of other anthropogenic disturbances such as habitat degradation, chemical pollution, invasive species introduction and climate change - on other ecosystem services such as climate and disturbance regulation, nutrient cycling, biological control and recreation (Costanza et al., 1997). These services are essential to human wellbeing and are not accounted for by commercial markets (Costanza et al., 1999; MEA, 2005).

\section{The performance of policies for fisheries governance}

In an effort to govern fisheries, policy makers, managers and, in a number of instances, fishers themselves have designed a wide set of fisheries policy instruments that can be organized into three broad groups: output or catch controls; input or effort controls; and technical measures (OECD, 1997). Output controls, such as total allowable catch, catch quotas and vessel catch limits, regulate the catches of a fishing fleet or individual fishers/boats. Input controls, consisting of limited licenses, effort quotas and gear and vessel restrictions, limit the number of boats or fishers in the fishery and regulate the type of fishing gear and the length of its use. Technical measures, such as time and area closures and size and sex selectivity through gear regulation, restrict the catch that can be achieved for a given amount of effort. These instruments are deployed either individually or in combination for the purpose of achieving a desired management objective. How they are deployed and what shape they ultimately take is influenced by the context, dominant societal values and world views, and the particular structure of the policy process of which they are 
Figure 3. Examples of industrial fishing vessels: (a) factory trawler; (b) long liner; (c) tuna purse seiner; and (d) shrimp dragger.

(a)

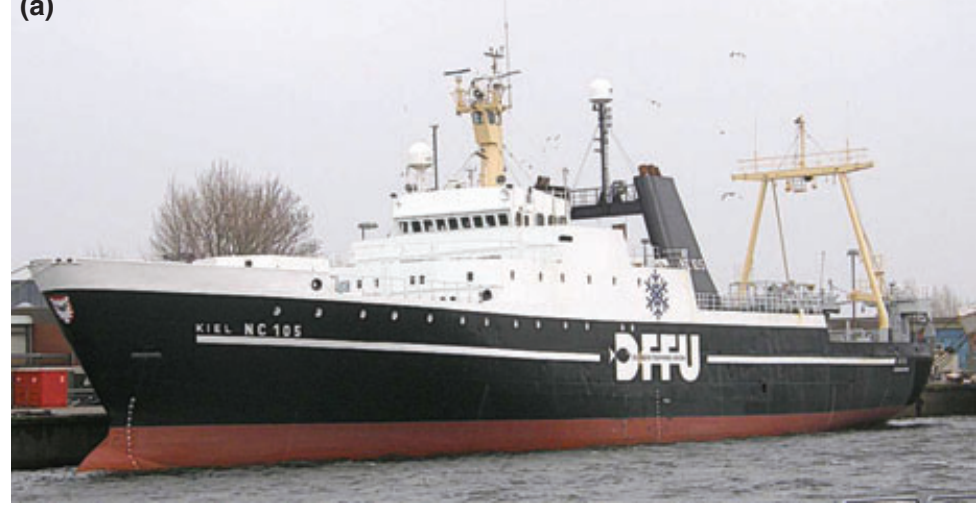

(c)

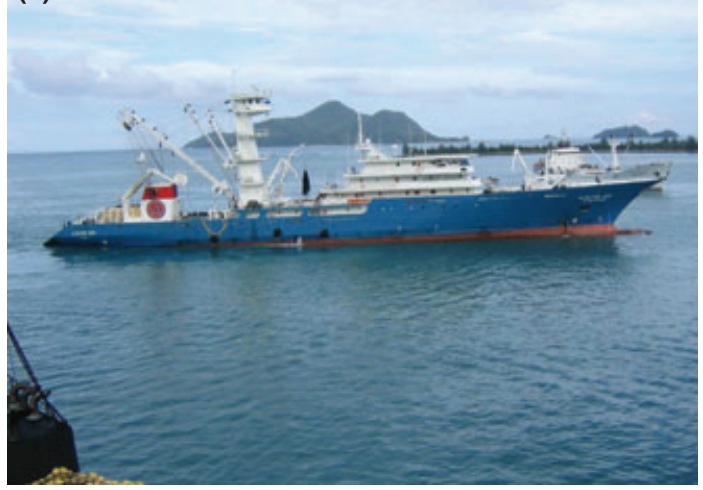

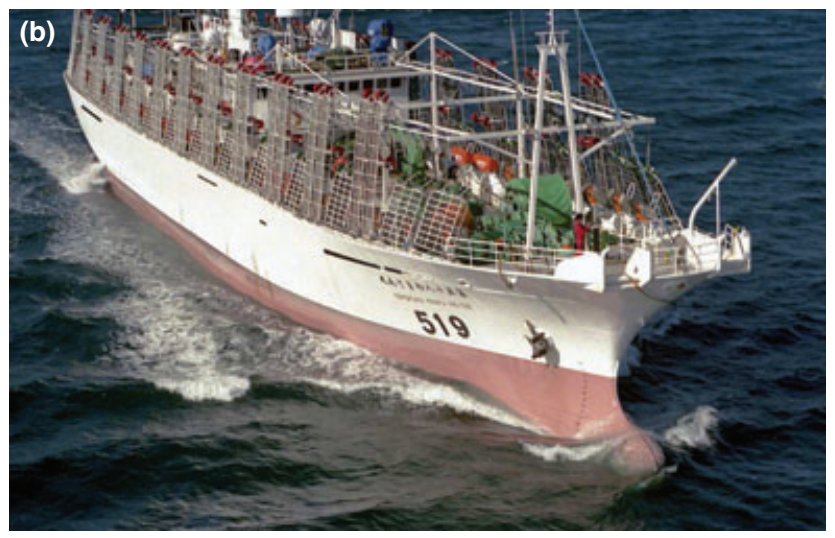

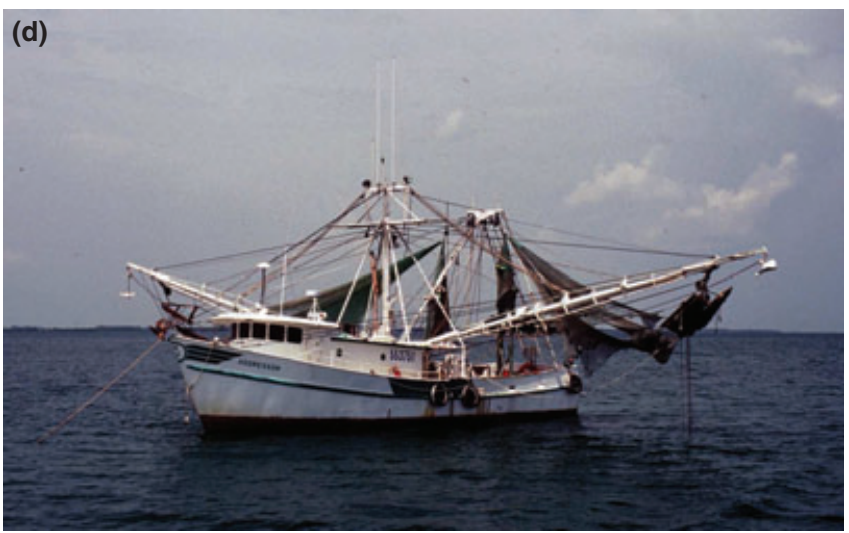

Source: Photo credits: (a) Ralf Bösch, 2008/Wikimedia; (b) Phillip Capper, 1988/Wikimedia; (c) Clipper, 2004/Wikimedia; (d) Wolcott Henry, 2005/Marine Photobank.

a part. For example, the same policy implemented through a top-down versus a bottom-up approach will likely perform and look very different (Ostrom, 2005). Furthermore, as Gray and Hatchard (2007) point out, a shift over the last two decades in dominant societal values and norms from resource utilization to environmental stewardship has left a marked imprint on the role and function of fisheries management.

A literature review on fisheries policy performance shows many different 'pockets' of knowledge but a lack of integration among them. For instance, scholars have made important contributions to our understanding of the economic losses due to open access (Gordon, 1954; Scott, 1955), the overreliance on market, state or even communal management policy approaches (Ostrom, 2007), the challenges of assigning well-defined property rights (Hanna, 2001; Hilborn et al., 2005b), the importance of shared management responsibilities, that is, comanagement (Armitage et al., 2007) or the impact of neoliberal fishery policies on local and traditional communities (Jentoft and McCay, 2003). Others have warned us about the risks of developing policies based solely on biological and economic data (Mahon et al., 2008;
McConney and Charles, 2010), and have criticized the implicit belief that the key to policy effectiveness lies in finding the right 'technical solution or fix' (Degnbol et al., 2006), while ignoring the role that the implementation process, including political will, issue framing, and power distribution and relations can play in policy performance (Mike Orbach, personal communication, 2010). Other scholars have analyzed the consequences of fishing fleets' overcapacity (Garcia and Grainger, 2005; Pauly et al., 2003) and the costs of fisheries subsidies which in 2003 approached $\$ 30$ billion (Sumaila et al., 2010). Wilson (2006) has pointed out that if we are to conceptualize fisheries as complex adaptive systems then we need to take more seriously the role of uncertainty and scale in policy design. This brief summary outlines important areas of knowledge about policy performance but also suggests that there is little integration among them.

\section{Emerging opportunities for a science of fisheries governance}

How can we start moving towards a systematic understanding of governance performance in fisheries? We 
contend that systematic accumulation of marine policy knowledge and integration useful to policy analysis will require the aid of a classificatory system. Classificatory frameworks (i.e. ontologies) have been commonplace throughout human history (e.g. ethno-classifications) to find order, patterns and understanding about the world, and are at the basis of any science or world view. Some disciplines such as biology, medicine and informatics, among others, rely on formal classificatory systems to lay out the nested nature of the elements of a particular complex system of interest (Madin et al., 2008; Rubin et al., 2008; Salafsky et al., 2008). Perhaps the bestknown classificatory system is the Linnaean taxonomic system, first proposed in 1735, which hierarchically classifies organisms based on a set of collectively agreed upon rules that allows knowledge accumulation. Where would biology be without it? And still, biologists would be quick to remind us that such socially construed heuristics ${ }^{1}$ are only analytical tools to work through complexity, not a statement about the world itself, which is necessarily much more complex.

Leaving important philosophical discussions aside, what would a classificatory system tailored to a fisheries policy science need to look like? It would need to treat fisheries as complex adaptive systems and to conceptualize them explicitly as social-ecological systems, where 'nature' and 'culture' are closely coupled and social and ecological variables are equally considered as potential causal conditions of the effects being investigated. While there are useful frameworks to analyze governance systems, for example the Interactive Governance and Governability Framework (Kooiman, 2008; Kooiman et al., 2008), few of them explicitly consider the ecological or natural aspects of the system in a multidisciplinary fashion. As Symes and Hoefnagel (2010) argue, based on their analysis of the Common Fisheries Policy of the European Union, we can achieve better and more effective fisheries governance only by engaging in multidisciplinary and collaborative research projects that effectively combine natural and social science factors into the analysis. Ostrom (2009) has proposed a framework which with further refinement could fulfill this basic requirement. Below we describe its general structure.

The social-ecological systems (SES) framework (Ostrom, 2007,2009 ) is a multi-tier classificatory system, developed at the Workshop in Political Theory and Policy Analysis at Indiana University as part of a more than 20year-old inquiry on the determinants of success in the governance of common-pool resources. Those familiar with the Institutional Analysis and Development (IAD) framework would recognize some of its elements embedded in the SES framework. A detailed description of the SES framework can be found in Ostrom (2007, 2009) and Poteete et al. (2010). In short, the SES frame- work recognizes that there are a large number of social and ecological variables that empirical studies have documented as related to governance performance of common-pool resources. The framework then organizes relationships among the many variables, suggests how they could be related across levels of analysis and among themselves, and shows where these variables are embedded within a system and how those systems are linked to even larger systems. For an illustration in the context of fisheries see Basurto and Ostrom (2009), who conducted a proof of concept study on the conditions under which small-scale fisheries in the Gulf of California, Mexico could overcome 'tragedies of the commons' and maintain successful self-organization over time.

The SES is multi-tiered and only the top tiers have begun to be developed. The top tier includes a set of variables common to any common-pool resource regardless of type or scale (i.e. fisheries, forests, irrigation systems, etc). These variables relate the resource systems (RS) and their units (RU) with governance systems (GS) and users (U). Together they generate interactions (I) and outcomes (O) (Figure 4). In the three cases of the small-scale fisheries discussed by Basurto and Ostrom (2009), the resource system is the inshore fishery sector and the resource units are the benthic sessile and semisessile mollusks harvested by fishers. The Social, Economic and Political Setting (S) is the Gulf of California in northwest Mexico near the border with the United States. As they describe in their analysis, by holding resource system and its units constant the authors are able to explore effects of the diverse patterns of interaction among different governance systems and users. In a different study and in contrast, an ecologist might be more interested in studying varying patterns in the resource system and its units while holding the governance system and attributes of users relatively constant (Poteete et al., 2010).

Figure 4. A multi-tier framework for analyzing a social-ecological system.

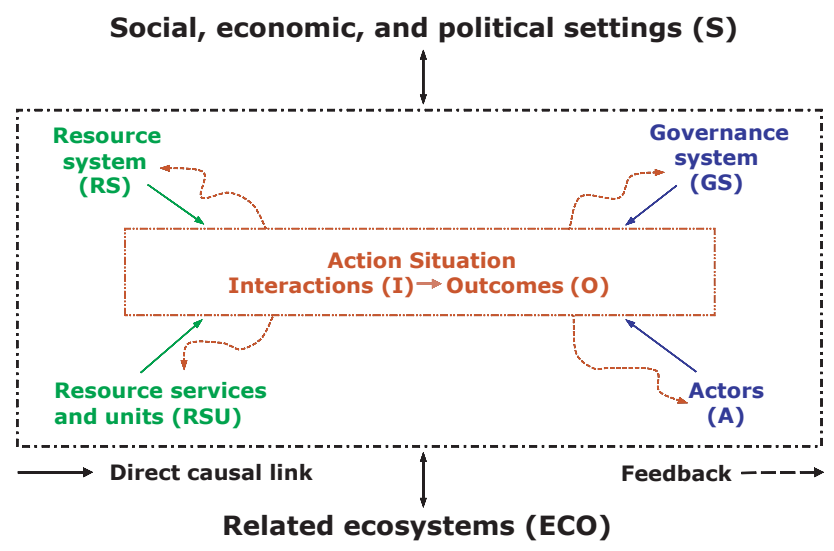

Source: Adapted from Ostrom, 2009, p. 420. 
Table 1. Second-tier variables in a framework for analyzing an SES

Social, Economic and Political Settings (S)

S1 - Economic development. S2 - Demographic trends. S3 - Political stability.

S4 - Government resource policies. S5 - Market incentives. S6 - Media organization.

Resource System (RS)

RS1 - Sector (e.g., water, forests, pasture, fish)

RS2 - Clarity of system boundaries ${ }^{*}$

RS3 - Size of resource system ${ }^{*}$

RS4 - Human-constructed facilities

RS5 - Productivity of system

RS5a - Indicators of the system ${ }^{*}$

RS6 - Equilibrium properties

RS7 - Predictability of system dynamics ${ }^{*}$

RS8 - Storage characteristics

RS9 - Location

Resource Units (RU)

RU1 - Resource unit mobility*

RU2 - Growth or replacement rate

RU3 - Interaction among resource units

RU4 - Economic value

RU5 - Size

RU6 - Distinctive markings

RU7 - Spatial \& temporal distribution

Interactions (I) $\rightarrow$ Outcomes (O)

11 - Harvesting levels of diverse users*

12 - Information sharing among users

13 - Deliberation processes

14 - Conflicts among users*

15- Investment activities

16 - Lobbying activities

Related Ecosystems (ECO)

ECO1 - Climate patterns. ECO2 - Pollution patterns. ECO3 - Flows into and out of focal SES.

Source: Adapted from Ostrom, 2007, p. 15183.

Note: The asterisks indicate the variables that are listed in Table 2, which were empirically identified by Basurto and Ostrom (2009).
Diagnosing the causal patterns that affect outcomes requires unpacking the system into a second tier containing a large number of potentially relevant variables. Table 1 illustrates the second-tier variables and constitutes an initial effort to help group and classify important variables in a tiered ontology. ${ }^{2}$ Table 2 shows those variables relevant for the analysis conducted by Basurto and Ostrom (2009). The SES framework helped Basurto and Ostrom better discern major similarities and differences among the three fishing communities that they investigated. For instance, the three fishing communities used the same fishing technology (U9) to harvest the same sessile resource (RU1), and enjoyed significant levels of autonomy to devise their own operational access and harvesting rules and norms (GS5). Only two communities, however, had local leadership (U5), based their interactions on high levels of trust and reciprocity (U6), showed high dependence on the resource to sus-
Governance System (GS)

GS1 - Government organizations

GS2 - Non-government organizations

GS3 - Network structure

GS4 - Property-rights systems ${ }^{*}$

GS5 - Operational rules ${ }^{*}$

GS6 - Collective choice rules*

GS7 - Constitutional rules*

GS8 - Monitoring \& sanctioning processes ${ }^{*}$

Users (U)

U1- Number of users ${ }^{*}$

U2 - Socioeconomic attributes of users

U3 - History of use

U4 - Location

U5 - Leadership/entrepreneurship ${ }^{*}$

U6 - Norms/social capital ${ }^{*}$

U7 - Knowledge of SES/mental models

U8 - Dependence on resource*

U9 - Technology used ${ }^{*}$

01 - Social performance measures

(e.g., efficiency, equity, accountability)

$\mathrm{O} 2$ - Ecological performance measures*

(e.g., overharvested, resilience, diversity)

O3 - Externalities to other SESs tain their livelihoods (U8) and successfully self-organized a governance structure that allowed them to avoid the 'tragedy of the commons', while the one lacking all those attributes did not. Of the two communities that self-organized, only one had formal property rights over its fishing areas (GS4) and was able to maintain its selforganized governance structure over time. This simple analysis can enable future comparisons with other communities that might share some of the same attributes (e.g. formal property rights (GS4)) but might perform differently - not being able to sustain self-organization over time - to understand further how different combinations of conditions might lead to the same (or different) governance outcomes.

As this framework continues to be developed into a tiered ontology, and scholars gain a better understanding of how concepts related to common-pool resources are embedded and related with each other, the third, 
Table 2. Comparison of key variables for three coastal fisheries in the Gulf of California

\begin{tabular}{llll}
\hline & Kino & Peñasco & Seri \\
\hline Users (U) & & & \\
U1 (number of users) & Rapid growth & Rapid growth & Slow growth \\
U5 (local leadership) & Absent & Present & Present \\
U6 (trust \& reciprocity) & Lacking & High levels & High levels \\
U7 (shared local knowledge - mental models) & Lacking & High levels & High levels \\
U8 (dependence on resource) & Low & High & High \\
U9 (technology) & Same & Same & Same \\
Governance System (G) & & & Present \\
GS4 (formal property rights) & Absent & Absent & Present \\
GS5 (operational rules) & Present & Present & Mostly present \\
GS8 (monitoring and sanctioning) & Mostly absent & Mostly present & \\
Resource System (R) & & & Small \\
RS3 (resource size) & Large & Small & Most available \\
RS5a (indicators) & Least available & Moderately available & Moderately predictable \\
RS7 (predictability) & Least predictable & Moderately predictable \\
Resource Units (RU) & & & Low \\
RU1 (Resource unit mobility) & Low & Low & Yos \\
Successfully self-organized & No & & Yos
\end{tabular}

Source: Adapted from Basurto and Ostrom, 2009, p. 50.

fourth and fifth tiers of the framework will be further elucidated, and some of the existing ones refined. As in the Linnaean system of classification, the initial tiers would be common to all systems, but subsequent tiers would increasingly differentiate them. While in tier one all marine fisheries policies will have most elements in common, tier four would look very different for a halibut fishery governed under an individual transferable quota in Alaska than for a lobster fishery in the Mexican Pacific coast governed under a territorial user rights system.

Although still in a very early phase of development (only the first two tiers have begun to be developed), one of the strengths of the framework is that it neatly brings together empirical findings from a large body of literature on the governance of social-ecological systems (Ostrom, 2007). Furthermore, putting ecological and social variables in the same plane encourages the development of a common language among social and natural science scholars, fostering a culture of understanding from which collaborations can follow.

As colleagues in medicine have demonstrated (Rubin et al., 2008), building a classificatory system does not come without important technical and political challenges. Perhaps the most formidable one is being able to address the coordination problems inherent in developing such a classificatory system. Well-defined rules on how to add or correct elements of the system or agreement on variable definitions are just a couple of examples. The benefits can be enormous and what has made the Linnaean and other similar classificatory systems robust over time has been the ability of scholars to engage in successful collective action to design rules by which to correct, add and maintain the system without destroying it. We hypothesize that those groups of fisheries policy scholars who are capable of addressing the coordination challenges of building a classificatory system will be in a much better position to address the formidable challenges facing global fisheries in the future than those who do not engage in such effort.

Already some scholars seem to be up for the challenge. The Workshop in Political Theory and Policy Analysis at Indiana University actively continues to refine and develop the framework. Since 2008, colleagues from the Netherlands, Germany, Sweden, Switzerland, Austria, Norway and the US have met in Potsdam, Germany, Stockholm, Sweden and Delft, the Netherlands to develop further the SES framework for analyzing the sustainability of social-ecological systems in a variety of contexts. While a solely marine SES focused on developing country scenarios is yet to be developed, these are encouraging first steps, constituting a promising opportunity to advance more effectively our understanding of what works, why and where in marine and fisheries contexts.

\section{Notes}

We thank Mike Orbach and Maja Schlüeter for their comments on previous drafts of this article.

1. The Linnaean classificatory system is a social construction except perhaps for the 'species' concept, although the advancement of genetics is starting to decompose this concept as well.

2. As Poteete et al. (2010) have argued, 'listing a variable in a framework is not equivalent to developing a well-defined theoretical question. No theory would include all of the second-tier 
variables (or the many third- and fourth-tier variables) that affect some of the important processes occurring within SESs. List of variables is not a theory'.

\section{References}

Armitage, D., Berkes, F. and Doubleday, N. (eds) (2007) Adaptive Co-management: Collaboration, Learning and Multi-level Governance. Vancouver: University of British Columbia Press.

Basurto, X. and Coleman, E. (2010) 'Institutional and Ecological Interplay for Successful Self-Governance of Community-Based Fisheries', Ecological Economics, 69 (5), pp. 1094-1103. DOI: 10.1016/ j.ecolecon.2009.12.001.

Basurto, X. and Ostrom, E. (2009) 'Beyond the Tragedy of the Commons', Economia delle Fonti di Energia e dell' Ambiente, 52 (1), pp. 35-60.

Bènè, C. (2006) Small-Scale Fisheries: Assessing their Contribution to Rural Livelihoods in Developing Countries. FAO Fisheries Circular 1008. Rome: Food and Agriculture Organization of the United Nations.

Berkes, F., Mahon, R., McConney, P., Pollnac, R. and Pomeroy, R. (2001) Managing Small-Scale Fisheries: Alternative Directions and Methods. Ottawa: International Development Research Centre.

Cinner, J. and McClanahan, T. (2006) 'Socioeconomic Factors that Lead to Overfishing in Small-Scale Coral Reef Fisheries of Papua New Guinea', Environmental Conservation, 33 (1), pp. 73-80. DOI: $10.1017 /$ S0376892906002748.

Cordell, J. and McKean, M. (1992) 'Sea Tenure in Bahia, Brazil', in D. Bromley (ed.), Making the Commons Work: Theory, Practice, and Policy. San Francisco, CA: Institute for Contemporary Studies, pp. 183-205.

Costanza, R., Andrade, F., Antunes, P., Van Den Belt, M., Boesch, D., Boersma, D. et al. (1999) 'Ecological Economics and Sustainable Governance of the Oceans', Ecological Economics, 31 (2), pp. 171-187. DOI: 10.1016/S0921-8009(99)00077-4.

Costanza, R., D'agre, R., De Groot, R., Farber, S., Grasso, M., Hannon, B. et al. (1997) 'The Value of the World's Ecosystem Services and Natural Capital', Nature, 387, pp. 253-260. DOI: 10.1038/ $387253 \mathrm{a} 0$.

Costello, C., Gaines, S. and Lynham, J. (2008) 'Can Catch Shares Prevent Fisheries Collapse?', Science, 321 (5896), pp. 1678-1681. DOI: 10.1126/science.1159478.

Dalzell, P., Adams, T. J. H. and Polunin, N. V. C. (1996) 'Coastal Fisheries in the Pacific Islands', Oceanography and Marine Biology: An Annual Review, 34, pp. 395-531.

Degnbol, P., Gislason, H., Hanna, S., Jentoft, S., Raakjêr Nielsen, J., Sverdrup-Jensen, S. et al. (2006) 'Painting the Floor with a Hammer: Technical Fixes in Fisheries Management', Marine Policy, 30 (5), pp. 534-543. DOI: 10.1016/j.marpol.2005.07.002.

Delgado, C. L., Wada, N., Rosegrant, M. W., Meijer, S. and Ahmed, M. (2003) Fish to 2020: Supply and Demand in Changing Global Markets. Washington, DC: International Food Policy Research Institute.

Devine, J., Baker, K. and Haedrich, R. (2006) 'Deep-Sea Fishes Qualify as Endangered', Nature, 439 (7077), p. 29. DOI: 10.1038/439029a.

Dyck, A. and Sumaila, U. (2010) 'Economic Impact of Ocean Fish Populations in the Global Fishery', Journal of Bioeconomics, 12 (3), pp. 227-243. DOI: 10.1007/s10818-010-9088-3.

FAO (2004) Report of the Second Session of the Working Party on Small-Scale Fisheries (Bangkok, Thailand, 18-21 November 2003). Fisheries Report 735. Rome: Food and Agriculture Organization of the United Nations.
FAO (2005) Review of the State of World Marine Fishery Resources. Fisheries Technical Paper 457. Rome: Food and Agriculture Organization of the United Nations.

FAO (2009) The State of World Fisheries and Aquaculture 2008. Rome: Food and Agriculture Organization of the United Nations.

FAO and Worldfish Center (2008) Small-Scale Capture Fisheries: A Global Overview with Emphasis on Developing Countries. A preliminary report of the Big Numbers Project.

Frank, K., Petrie, B., Choi, J. and Leggett, W. (2005) 'Trophic Cascades in a Formerly Cod-Dominated Ecosystem', Science, 308 (5728), pp. 1621-1623. DOI: 10.1126/science. 1113075.

Froese, R. and Kesner-Reyes, K. (2002) Impact of Fishing on the Abundance of Marine Species. ICES and FAO Report 2002/L:12.

Garcia, S. and Grainger, R. (2005) 'Gloom and Doom? The Future of Marine Capture Fisheries', Philosophical Transactions of the Royal Society B: Biological Sciences, 360 (1453), pp. 21-46. DOI: 10.1098/rstb.2004.1580.

Gelcich, S., Hughes, T., Olsson, P., Folke, C., Defeo, O., Fernandez, M. et al. (2010) 'Navigating Transformations in Governance of Chilean Marine Coastal Resources', Proceedings of the National Academy of Sciences, 107, pp. 16794-16799. DOI: 10.1073/ pnas.10120 21107.

Gordon, H. S. (1954) 'The Economic Theory of a Common-Property Resource: The Fishery', Journal of Political Economy, 62, pp. 124142.

Gray, T. S. and Hatchard, J. (2007) 'Environmental Stewardship as a New Form of Fisheries Governance', ICES Journal of Marine Science, 64, pp. 786-792. DOI: 10.1093/icesjms/fsl041.

Hampton, J., Sibert, J., Kleiber, P., Maunder, M. and Harley, S. (2005) 'Decline of Pacific Tuna Populations Exaggerated?', Nature, 434 (7037), pp. E1-2. DOI: 10.1038/nature 03582.

Hanna, S. (2001) 'Managing the Human-Ecological Interface: Marine Resources as Example and Laboratory', Ecosystems, 4 (8), pp. 736-41.

Hawkins, J. and Roberts, C. (2004) 'Effects of Artisanal Fishing on Caribbean Coral Reefs', Conservation Biology, 18 (1), pp. 215-226. DOI: 10.1111/j.1523-1739.2004.00328.x.

Hilborn, R., Orensanz, J. M. and Parma, A. M. (2005a) 'Institutions, Incentives and the Future of Fisheries', Philosophical Transactions of the Royal Society B: Biological Sciences, 360 (1453), pp. 47-57. DOI: 10.1098/rstb.2004.1569.

Hilborn, R., Parrish, J. and Litle, K. (2005b) 'Fishing Rights or Fishing Wrongs?', Reviews in Fish Biology and Fisheries, 15 (3), pp. 191199. DOI: 10.1007/s11160-005-5138-7.

Jackson, J. B. C., Kirby, M. X., Berger, W. H., Bjorndal, K. A., Botsford, L. W., Bourque, B. J. et al. (2001) 'Historical Overfishing and the Recent Collapse of Coastal Ecosystems', Science, 293 (5530), pp. 629-637. DOI: 10.1126/science.1059199.

Jentoft, S. and McCay, B. (2003) 'The Place of Civil Society in Fisheries Management', in D. C. Wilson, J. Nielsen and P. Degnbol (eds), The Fisheries Co-management Experience: Accomplishments, Challenges, and Prospects. Dordrecht: Kluwer Academic Publishers, pp. 293-308.

Johannes, R. E. (2002) 'The Renaissance of Community-Based Marine Resource Management in Oceania', Annual Review of Ecology and Systematics, 33, pp. 317-340.

Johnson, D. S. (2006) 'Category, Narrative, and Value in the Governance of Small-Scale Fisheries', Marine Policy, 30 (6), pp. 747756. DOI: 10.1016/j.marpol.2006.01.002.

Kooiman, J. (2008) 'Exploring the Concept of Governability', Journal of Comparative Policy Analysis: Research and Practice, 10 (2), pp. 171-190. DOI: 10.1080/13876980802028107. 
Kooiman, J., Bavinck, M., Chuenpagdee, R., Mahon, R. and Pullin, R. (2008) 'Interactive Governance and Governability: An Introduction', The Journal of Transdisciplinary Environmental Studies, 7 (1), pp. 1-11.

Lotze, H., Lenihan, H., Bourque, B., Bradbury, R., Cooke, R., Kay, M. et al. (2006) 'Depletion, Degradation, and Recovery Potential of Estuaries and Coastal Seas', Science, 312 (5781), pp. 1806-1809. DOI: 10.1126/science. 1128035.

Madin, J., Bowers, S., Schildhauer, M. and Jones, M. (2008) 'Advancing Ecological Research with Ontologies', Trends in Ecology \& Evolution, 23 (3), pp. 159-168.

Mahon, R., McConney, P. and Roy, R. (2008) 'Governing Fisheries as Complex Adaptive Systems', Marine Policy, 32 (1), pp. 104-112. DOI: 10.1016/j.marpol.2007.04.011.

McConney, P. and Charles, A. (2010) 'Managing Small-Scale Fisheries: Moving towards People-Centered Perspectives', in R. Grafton, R. Hilborn, D. Squires, M. Tait and M. Williams (eds), Handbook of Marine Fisheries Conservation and Management. New York: Oxford University Press, pp. 532-545.

MEA (2005) Ecosystems and Human Well-Being: Synthesis. Washington, DC: Island Press.

Murawski, S., Methot, R. and Tromble, G. (2007) 'Biodiversity Loss in the Ocean: How Bad is It?', Science, 316 (5829), pp. 1281-1285. DOI: $10.1126 /$ science.316.5829.1281b.

Myers, R. A., Baum, J. K., Shepherd, T. D., Powers, S. P. and Peterson, C. H. (2007) 'Cascading Effects of the Loss of Apex Predatory Sharks from a Coastal Ocean', Science, 315 (5820), pp. 18461850. DOI: $10.1126 /$ science. 1138657.

Myers, R. A. and Worm, B. (2003) 'Rapid Worldwide Depletion of Predatory Fish Communities', Nature, 423, pp. 280-283. DOI: 10.1038/nature01610.

Newton, K., Cote, I., Pilling, G., Jennings, S. and Dulvy, N. (2007) 'Current and Future Sustainability of Island Coral Reef Fisheries', Current Biology, 17 (7), pp. 655-658. DOI: 10.1016/j.cub.2007. 02.054.

Norse, E. A. and Watling, L. (1999) 'Impacts of Mobile Fishing Gear: The Biodiversity Perspective', American Fisheries Society Symposium, 22, pp. 31-40.

OECD (1997) Towards Sustainable Fisheries: Economic Aspects of the Management of Living Marine Resources. Paris: Organisation for Economic Cooperation and Development.

Ostrom, E. (2005) Understanding Institutional Diversity. Princeton, NJ: Princeton University Press.

Ostrom, E. (2007) 'A Diagnostic Approach for Going beyond Panaceas', Proceedings of the National Academy of Sciences, 104 (39), pp. 15181-15187. DOI: 10.1073/pnas.07022 88104.

Ostrom, E. (2009) 'A General Framework for Analyzing Sustainability of Social-Ecological Systems', Science, 325 (5939), pp. 419-422. DOI: 10.1126/science.1172133.

Pauly, D. (2006) 'Major Trends in Small-Scale Marine Fisheries, with Emphasis on Developing Countries, and some Implications for the Social Sciences', Maritime Studies (MAST), 4 (2), pp. 7-22.

Pauly, D., Alder, J., Bennett, E., Christensen, V., Tyedmers, P. and Watson, R. (2003) 'The Future for Fisheries', Science, 302 (5649), pp. 1359-1361. DOI: 10.1126/science. 1088667.

Pauly, D., Christensen, V., Guènette, S., Pitcher, T., Sumaila, U., Walters, C. et al. (2002) 'Towards Sustainability in World Fisheries', Nature, 418, pp. 689-695. DOI: 10.1038/nature01017.
Pauly, D., Watson, R. and Alder, J. (2005) 'Global Trends in World Fisheries: Impacts on Marine Ecosystems and Food Security', Philosophical Transactions: Biological Sciences, 360 (1453), pp. 5-12. DOI: 10.1098/rstb.2004.1574.

Poteete, A., Janssen, M. and Ostrom, E. (2010) Working Together: Collective Action, the Commons, and Multiple Methods in Practice. Princeton, NJ: Princeton University Press.

Rubin, D. L., De Abreu Moreira, D., Kanjamala, P. P. and Musen, M. A. (2008) 'Symbiotic Relationships between Semantic Web and Knowledge Engineering'. AAAI Spring Symposium Series, Stanford University.

Salafsky, N., Salzer, D., Stattersfield, A., Hilton-Taylor, C., Neugarten, R., Butchart, S. et al. (2008) 'A Standard Lexicon for Biodiversity Conservation: Unified Classifications of Threats and Actions', Conservation Biology, 22 (4), pp. 897-911. DOI: 10.1111/j.15231739.2008.00937.x.

Scott, A. (1955) 'The Fishery: The Objectives of Sole Ownership', The Journal of Political Economy, 63, pp. 116-124.

Srinivasan, U., Cheung, W., Watson, R. and Sumaila, U. (2010) 'Food Security Implications of Global Marine Catch Losses due to Overfishing', Journal of Bioeconomics, 12 (3), pp. 183-200. DOI: 10.1007/s10818-010-9090-9.

Sumaila, U., Khan, A., Dyck, A., Watson, R., Munro, G., Tydemers, P. et al. (2010) 'A Bottom-Up Re-estimation of Global Fisheries Subsidies', Journal of Bioeconomics, 12 (3), pp. 201-225. DOI: 10.1007/s10818-010-9091-8.

Symes, D. and Hoefnagel, E. (2010) 'Fisheries Policy, Research and the Social Sciences in Europe: Challenges for the 21st Century', Marine Policy, 34, pp. 268-275. DOI: 10.1016/j.marpol.2009.07.006.

Wilson, J. (2006) 'Matching Social and Ecological Systems in Complex Ocean Fisheries', Ecology and Society [online], 11 (1). Available from: http://www.ecologyandsociety.org /vol11/iss1/art9/ [Accessed 18 July 2010].

Worm, B., Barbier, E. B., Beaumont, N., Duffy, J. E., Folke, C., Halpern, B. S. et al. (2006) 'Impacts of Biodiversity Loss on Ocean Ecosystem Services', Science, 314 (5800), pp. 787-790. DOI: 10.1126/ science.1132294.

Worm, B., Hilborn, R., Baum, J., Branch, T., Collie, J., Costello, C. et al. (2009) 'Rebuilding Global Fisheries', Science, 325 (5940), pp. 578-85. DOI: 10.1126/science.1173146.

Ye, Y. (1999) Historical Consumption and Future Demand for Fish and Fishery Products: Exploratory Calculations for the Years 2015-2030. FAO Fisheries Circular 946. Rome: Food and Agriculture Organization of the United Nations.

\section{Author Information}

Xavier Basurto is Assistant Professor of Sustainability Science at Duke Marine Lab, Nicholas School of the Environment, Duke University. His research experience includes the governance of coastal marine resources in developing country contexts.

Mateja Nenadovic is a PhD student at the Program in Marine Science and Conservation, Duke Marine Lab, Nicholas School of the Environment, Duke University. His research interests focus on governance of marine social-ecological systems. 